Article

\title{
The Role of Villages and Townships in Informal Land Development in China: An Investigation on the City Fringe of Beijing
}

\author{
Pengjun Zhao * and Mengzhu Zhang \\ Centre for Urban Planning and Transport Studies, School of Urban and Environmental Sciences, \\ Peking University, Yiheyuan Road 5, Beijing 100871, China; mengzhu.zhang@pku.edu.cn \\ * Correspondence: pengjun.zhao@pku.edu.cn; Tel.: +86-10-6276-8005 \\ Academic Editor: Yehua Dennis Wei \\ Received: 15 January 2016; Accepted: 4 March 2016; Published: 9 March 2016
}

\begin{abstract}
The past decades have witnessed a number of informal land developments on the urban fringe in China although many strict state regulations have been made to control this. The dual urban rural land system is widely believed to be one major determinant of informal developments in the existing literature. However, the important role of local villages and townships are often neglected. This paper aims to shed light on this by looking at the gated informal housing communities in Beijing as a case study. It investigates the role of villages and townships in informal land development and the conflicts of interest that arise with state regulations in the context of political decentralization. The results of analysis show that township governments have an ambivalent attitude or even give tacit approval to informal land development in villages since these informal developments actually bring economic benefits to local villagers and themselves. The situation seems to be worse as townships have poor fiscal capacity and a growing administrative responsibility for improvement of local development in the context of decentralization. Villages are keen to capture economic benefits from informal land development with help from private developers. As a result, a local, informal coalition between townships, villages, and private developers emerged at the grass roots level. This presents a major challenge to the state regulations designed for sustainable urban growth management.
\end{abstract}

Keywords: informal land development; informal housing; urban growth; township government; decentralization

\section{Introduction}

Informal land development in China usually refers to urban development (housing or industrial development) on land without land use permission or planning approval from the state, or development on land that does not comply with land use planning and development regulations. Informal land development in China has increasingly drawn the attention of both the public and academics. Informal housing, in particular, accounted for $20 \%$ of the total land used for housing in China in 2010 [1], while informal land development in general has seriously jeopardized sustainable development, causing the loss of arable land [2] and land loss by farmers [3], as well as spurring informal housing [4,5] and urban sprawl [6]. In this context, informal development may be a spontaneous response from villages to a shortage of fiscal revenue and the need to find ways to improve local people's livelihoods. As a result, local residents have protested strongly against the government's demolition of informal housing in villages, such as occurred in Hainan, Guangdong, Beijing, Hebei, and Jiangsu [7-11]. The issues surrounding informal land development now actually go beyond land development as such, having become a political issue for China's governments with respect to social stability. 
Informal land development in China has occurred in the context of political and economic transition. This transition is characterized by several simultaneous processes, including decentralization, marketization, and privatization [12,13], which have significantly changed the relationship between government and the market. The phenomenon of urban entrepreneurialism has been recognized in the context of the decentralization and transition of the Chinese market [14], whereby local and city governments have started to transform into market-friendly agents with their key goals being to establish alliances with developers and investors to promote local economic growth. The focus of city agendas now lies on economic planning, with a shift in the role of government from public "welfare providers" to "economic development managers." In this context, local governments have been struggling to attract capital and investment. At the same time, local governments (whether a city government, a district or country government, or a township government) have gained more decision-making powers from the central government to control the resources under their jurisdiction [13]. The sale of land, in particular rural land, is one vital way that local governments can accumulate capital and obtain fiscal revenue [15].

The transition process has also changed the relationship between the central and local governments, with the state giving more power to the latter. These local governments can now focus on particular policies that promote local economic growth, rather than on state development goals. In this context, the phenomena of "local-state corporatism" [16] and "growth coalitions" [17,18] have emerged and are now predominant in local development. The former refers to the fact that local governments may now cooperate with enterprise to support key industries or programs. Unfortunately, these are usually closely related to the explicit short-term goal of economic growth, with cooperation established on the basis of irrational and unsustainable policy and often at the expense of vulnerable groups [16-19]. The latter implies that an interested coalition of local politicians and stakeholders use their political power and capital to obtain huge profits or more political power. The real estate industry, for example, is a typical battlefield on which such coalitions make a grab for and accumulate wealth [18]. In this context, rural land, which is the most valuable and tractable of resources in the urban region, is inevitably dragged into the waves of the 'growth coalition' to be developed formally or informally.

There are many factors affecting informal land development. It is widely believed that the conflict between the state government and villagers over who receives the economic benefits of land development is one major reason $[2,19,20]$. In many cases, the state government expropriates rural land from villagers, while offering minimal financial compensation and selling the land on the market at a much higher price. This formal land development process has been criticized for causing a considerable loss of economic benefits to villagers and a decline in the quality of life of farmers who have lost their land [20]. Therefore, informal land development is often considered as one way in which villages and villagers can obtain another source of income or protect their own welfare [3].

However, this dualistic mainstream view that regards villages and the government as two opposing sides does not tell the whole story of informal land development in China. Some puzzles remain: Why does informal land development still occur despite the central government's attempts to control it through new policy? Why are the state government's regulations for land use in rural areas ineffective and impracticable? It is widely believed that certain aspects of the existing governance system could be important explanatory factors [20,21]. However, it should also be recognized that the role of township governments, which are the primary units of government administration in China's rural areas, could be an important factor in informal land development in the rural areas. Firstly, township governments are usually powerless to control informal land developments in villages. Secondly, in many cases, township governments even support informal land development for the sake of achieving local economic growth [20,21]. The precise role of township governments could thus be a key issue in relation to informal land development in China.

However, this role is often ignored in the existing theoretical explanations, which talk of urban entrepreneurialism, "local-state corporatism" and "growth coalitions." Generally, a township may play two roles. On the one hand, a township government is the state authority at the grassroots level, 
and it is the direct manager of various activities also the executor of the state laws and regulations specifically in the rural area. However, the enforcement powers of township governments have been highly restrained since the introduction of China's new Constitution in 1982, which established a regime of village autonomy in rural areas. Since then, there has been a slow retreat of state government power from the internal affairs of villages [22]. Consequently, the village cadres now manage internal affairs and also negotiate about external affairs on behalf of the villagers. These cadres are selected directly by villagers through democratic elections. Moreover, a township government has no power to appoint and dismiss village cadres and intervene in the internal affairs of the village, despite the fact that the village lies directly under its administrative jurisdiction. In many cases, the role of the township government in rural areas has actually shifted from a powerful governor to a development collaborator with villages [22]. This transition has significantly weakened the executive power and authority of township governments, including their capacity to manage informal land development in villages.

At the same time, township government is also undergoing a process of transformation to a service-oriented government, driven by China's marketization and decentralization [23], while under the ambitious goals of growth driven by the city government, maintaining social stability has become the priority task of township government. The improvement of local livelihoods by undertaking to reduce unemployment, increase villagers' income, and build roads and schools has become the most important mission of township governments $[6,18,20]$. However, the low levels of fiscal revenue received by township governments barely match these heavy responsibilities of providing public services and infrastructure in rural areas [22].

In such a context, informal land development on collective village land is one significant way that villages can increase their income and improve their quality of life. From this perspective, township government shares the same goals as the villages, rather than those of the state and municipal governments. Supported by financial resources from informal land development, villages are able to provide for their own livelihoods, compensating for the lack of welfare from the state government in the context of the dual rural-urban social security system. Consequently, township government may exhibit a unique attitude to informal land development, which could play a positive role in improving villagers' livelihoods in rural areas.

This study thus aims to explore informal land development in China, taking a perspective that is quite different from the conventional approach to informal land development, which considers it to be the result of the existing dual urban-rural land ownership system $[2,4,13,19]$. In contrast, the study addresses the failure of the implementation of state government land development regulations in rural areas. The paper focuses on the roles of township government, villages and private developers in the context of the process of decentralization and marketization in China, looking at the specific case of informal land development in Doudian town in the rural area of the municipality of Beijing. Officials from the township government were interviewed for the purpose of the study. It is on the basis of these interviews that the communication and interaction between various levels of government and the conflict between state regulations and the township government's responses to informal land development in villages under its jurisdiction will then be discussed.

\section{Informal Land Development in China: A Theoretical Review of the Institutional Factors}

Institutions "are the rules of the game in a society, or more formally, are the humanly devised constraints that shape human interaction" [24]. When it comes to institutions related to urban planning in China, there are four levels of institutions: informal institutions, which are deeply embedded values, norms, customs, and traditions; formal institutions, which are rules codified by laws, regulations, administrative orders, and administrative statutes; governance institutions; and resource allocation institutions [25]. The paper analyses institutional factors affecting informal land development. Four types of institutional factors are addressed: land use management and planning (the dual urban-rural land system), governance structure and political decentralization, resource 
allocation and distribution of land benefits, and the attitudes of township government and officials to informal land development.

\subsection{Seeds of Informality: the Dual Urban-Rural Land System}

There has been extensive research on informal land development in China as it is increasingly drawing the attention of both the public and politicians [1,4,15]. Unlike informal land development in Latin America [26] and south Asia [27], where the core issue concerns the informal development of slums due to poverty in the context of rapid urbanization, in China, land use rights are the core issue in relation to the 'informality' of informal land development $[4,28]$. It is widely believed that informal land development in China is largely affected by the dual urban-rural land system $[1,4,15]$.

This system was introduced in the 1950s. According to China's Constitution, there are two kinds of land ownership in China: state-owned land and collectively owned land. In urban areas, most land is owned by the state government and managed by a municipal government on behalf of the state. However, in rural areas, land is collectively owned by villagers. The village committee, which is selected by villagers, is responsible for the management of land in a village. Accordingly, there are two different forms of land use rights in China. The state government has full property rights to urban land, and this land use right can be transferred to the market. However, villages that own rural land do not have complete land property rights. Rural land may not be sold on the market unless the state government gives permission. If villagers and villages want to sell their land for development, they must first sell it to the state government. As a result, the state government monopolizes the land market and has exclusive power to set prices when they purchase land from the village farmers. In most cases, villagers receive a small amount of compensation for the loss of their land, while the state government gains considerable benefits in the form of land-transaction fees [1,29]. More specifically, rural land use is legally divided into three types: farmland, homestead land, and collective construction land. Farmland is limited to agricultural use. Homestead land is restricted to construction of houses that are only in resided by villagers themselves. The size and location of homestead land are fixed and allocated by township government according to household size. This means that when a family has new members, it can apply to the township government for more homestead land. The construction land in a village is only to be used to build the village's infrastructure and develop enterprise activities that promote the village's collective economy. According to the state land management regulations, any use that is inconsistent with these three types is considered to be illegal or informal. In other words, villagers actually do not have the same rights related to urban use or related developments, although they are considered to have ownership of rural land.

Informal land development in villages has several key characteristics [1]. Firstly, it involves the illegal development of rural land for urban uses; in most situations this means profitable housing or real estate development. Secondly, the development process has no permission from the land, planning, or construction authorities. The whole process, including the design, construction, and sale, remain private, and beyond any government control or authorization. Thirdly, the purpose of informal land development is to make a profit by selling the housing. These prices are far beyond the villagers' budgets and offer no improvement to their quality of life.

The dual land system has caused a state monopoly on the urban land market. Villages that have farmland use rights are not allowed to sell their land directly on the market. They must sell their land to the state and transfer their collective owned land to the state. As a result, the state government and its representative governments (provinces and municipal governments) have an exclusive right to sell land to private developers according to the existing regulations. In this sense, the state government is officially entitled to gain huge profits from selling villagers' land. This could have two main effects on informal land development. Firstly, the monopoly land market increases land prices and housing prices. The demand on informal housing with a low price is increasing, which drives informal land development. Secondly, the monopoly land market reduces villages' economic benefits from land 
development. This could force them to gain their own interests through informal land development. More details will be discussed in Section 3.

\subsection{Decentralization: Imbalance in Central/Local Fiscal Responsibilities}

A lack of balance in the central/local fiscal relationship increases pressure on city governments to pursue alternative sources of fiscal revenue in the context of decentralization in China. The reform of the tax distribution system in 1994 is considered a milestone of decentralization. The purpose of this system was to establish separate fiscal systems for the central and local governments. This taxation reform is considered to offer incentives to marketization by giving some autonomous tax rights to local governments. However, these autonomous rights remain very limited and this central/local tax distribution system is considered to have created an imbalance in fiscal income between central and local governments, with the former taking the greater part and the high-value taxes, leaving local government with fewer taxes of lesser value. For example, added-value tax is the most important and valuable tax in China, accounting for over $60 \%$ of total tax revenue. However, according to the new tax distribution system, the central government takes $75 \%$ of added-value tax and local government the remaining $25 \%$. This lack of balance in the central/local tax distribution has put huge fiscal pressures on city governments. For example, in Guangzhou, which is one of the most developed cities in China, the total tax revenue in 2012 was CNY 3379 billion. However, more than 75\% of this was handed over to the central government [30].

In the meantime, city governments have come to be predominantly responsible for managing local public affairs, including providing public services and welfare. This trend was further strengthened by the increase in local autonomy in the context of decentralization. Currently, the central government is responsible for managing national affairs using state taxes, while local governments are responsible for providing local public services and infrastructure relying on local tax revenue. These local public services primarily include education, medical care, social housing, roads, etc. As the tax revenue of city governments is rather limited, they face huge pressures in providing these local public services. In particular, rapid urbanization, which has taken the form of an annual increase of nearly 10 million people in China's cities, has only worsened the situation. This lack of balance between fiscal revenues and responsibilities is thus pushing city governments to find other ways to increase local fiscal revenues, such as by selling land. A local revenue system based on "land financing" is emerging right at this moment.

"Land financing" refers to the fact that city governments heavily depend on selling land to gain fiscal revenue, and this is accepted by the central government. Land-transaction fees can be seen as compensation for insufficient local tax revenues since 1994. However, within a short span of two decades, "land financing" has gone far beyond rational levels. In many cities, the revenue from selling land accounted for $40 \%$ of total local fiscal revenue in 2012. In some cities, such as Hangzhou and Foshan, this percentage even went as high as $70 \%$. In the context of "land financing", city governments compete for land resources. Because urban land is limited, rural land in the suburbs has become the main source of 'land financing' over the last two decades [15].

At the same time, township governments, villages, and villagers have also been attracted by the considerable economic benefits of selling land. The tax distribution reform also created fiscal pressures on township governments. In particular, the central government abolished the national agricultural tax in 2006, which was one of the main sources of fiscal revenue of township governments. Many studies have confirmed that township governments in China are now facing a financial dilemma [22,31,32]. In rural areas, a "Xiang cai xian guan" fiscal system is applied, which means that township revenues are managed by a county government rather than by a township itself. County government is an administrative unit under the city government, but is a higher level administrative unit than a township government. According to the system, township fiscal revenues should be submitted to a county government first, which then makes a fiscal budget and transfers revenues to the township government. Although this fiscal system effectively curbs corruption, it reduces the fiscal autonomy of the township 
government [22]. Moreover, if a county government is in financial crisis, township revenues are often misappropriated and withheld. This is a common problem among China's township governments [22].

As a result of these factors, township governments are in a disadvantaged position when it comes to receiving a fair share of fiscal revenues. Moreover, township governments are expected to take responsibility for providing public services in their territory. In the context of the current administration system, township governments are actually required to be responsible for a variety of local affairs. They are often considered to be "small but comprehensive" [22]. As a result, township governments may give permission for informal land development to villages in order to fulfill their responsibility to improve local livelihoods and gain some fiscal income from the villages at the same time.

To sum up, decentralization is a key contributor to the growth of informal land development. On one hand, political decentralization causes a withdrawal of the state command control to local governments. A township government is given more rights to make decisions about land development inside their administrative boundary. In many cases, township government could give permission for informal development. On the other hand, political decentralization means fiscal autonomy for local governments. Both municipal governments and township governments are facing an increasing pressure to supply public services to local people in the context of rapid urbanization. Revenue from selling land and tax from property trade have become important income resources for many local governments. Township governments could permit villages for informal land development since informal land development can bring economic benefits to both villagers and township governments, and thus relieve township governments' fiscal burdens.

\subsection{Unfair Distribution of Land Benefits}

The question arises: why do villages and villagers not choose a formal way to develop their land rather than an informal method? As mentioned above, city governments, on behalf of the state government, actually monopolize the land market. Rural land cannot be used and developed for urban activities unless the land is sold to a city government first and transferred from collectively owned to state-owned urban land; in other words, villagers do not have a land use right that encompasses urban activities. Nevertheless, the process of transferring rural land to urban land produces massive added value that mostly benefits the city government. This unfair distribution of the economic benefits of land development is a key incentive for villages and villagers to develop their own land themselves, rather than sell it to a city government $[1,4,15]$.

According to the current land laws and regulations of China, rural land development for urban use can only be conducted by a city government through a formal procedure (Figure 1). Firstly, the city government expropriates the rural land from villages and pays land expropriation compensation to the villages/villagers. Secondly, the city government transforms the expropriated rural land into urban land by changing the planning laws or regulations that apply to it. Thirdly, the city government sells the land use right to developers and obtains land-transfer fees. Afterwards, the land is developed and the properties are sold or rented on the market. Notably, the land-transfer fee obtained by the city government and the added value of the property obtained by the developers are hundreds of times the amount of the land expropriation compensation paid to the villagers. According to current land management law, the standard for land expropriation compensation to villagers is based on the land's agricultural production value but not the added value on the market, which is equivalent to about 10 to 30 times the actual agricultural production. For example, one hectare of farmland might produce 15,000 kilograms of grain, which is worth about CNY 30,000. However, when this one hectare of farmland is sold on the market, the city government could receive revenue of about CNY 90 million. More specifically, some studies have estimated that in a formal rural land development process, villages and villagers only obtain $5 \%$ to $10 \%$ of the total benefits, while the government obtains $30 \%$ and the developer $40 \%[1,29]$. In this context, informal land development by villages can be seen as a form of resistance to the appropriating of land benefits by the state government $[1,4]$. 


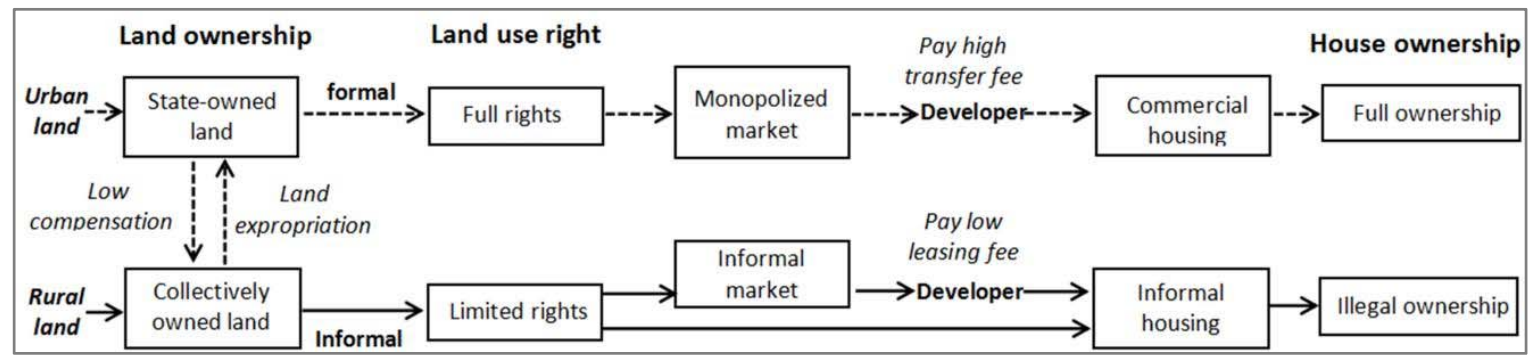

Figure 1. The process of formal and informal land development in China. Source: the authors.

Informal land development in villages primarily occurs in one of two patterns (Figure 2). The first is when a village develops rural land in the village by itself. In this scenario, the village raises funds for housing or commercial development and the land development process is completely controlled by the village committee. After the housing is developed, the village sells the housing on the market. The second pattern is more likely to occur in a situation where funds are insufficient. In this case, villages collaborate with private developers in informal land development. Such a collaboration is usually organized in the form of a village-developer cooperation alliance. In both cases, the key purpose is to capitalize on and profit from the added value of selling rural land on the market. By taking this informal approach, villages and villagers can directly control the distribution of benefits. It has been estimated that by conducting informal rural land development, villages and villagers obtain $70 \%-100 \%$ of the total benefits, while the developer obtains $30 \%$ and the city government reaps no benefits $[1,29]$.

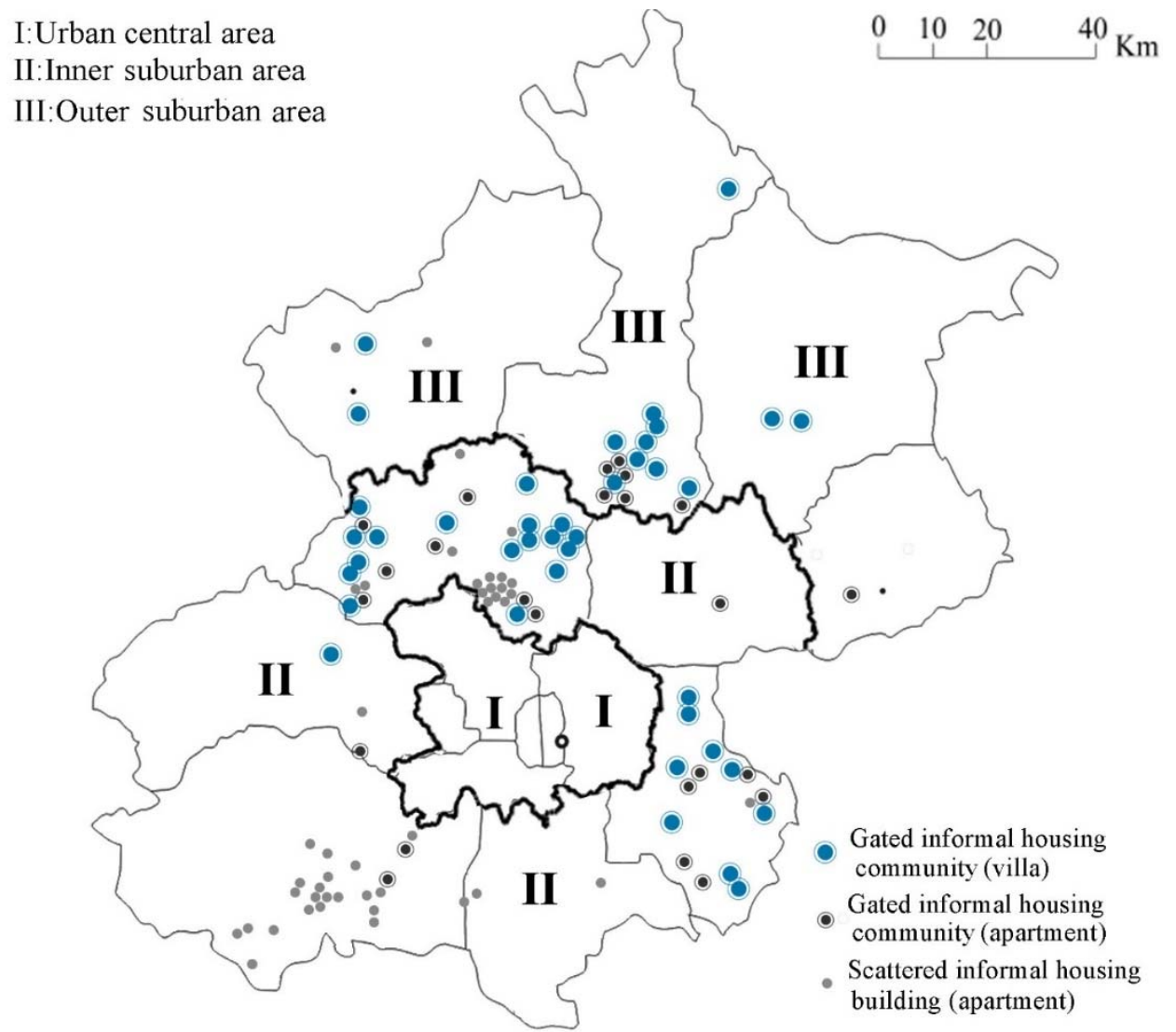

Figure 2. The location of informal housing in Beijing. Source: the authors. 


\subsection{Fragmented Management across Governments}

It is noteworthy that development management has become fragmented in the process of decentralization and marketization. Different levels of government do not always share the same goals [20]. There is empirical evidence for such fragmented management of land development; for example, in Canton [33] and Hainan [20], to name just two. This can be explained from two perspectives: the complicated relationship between the central and city governments, and the changing relationship between city and township governments.

As mentioned above, economic growth is a common goal of both the central and city governments. Urban growth is in the nature of an entrepreneurial city government [34], which most Chinese city governments have now become [13]. However, the central government is also greatly concerned about enhancing its food supply and food security in the context of rapid urbanization. A rigorous goal of $90 \%$ food self-sufficiency has been highlighted by the central government. Therefore, it takes a strong position on the preservation of farmland or arable land. The Ministry of Land and Resources is a rather powerful bureaucratic force that issues strict farmland preservation goals and specific targets to city governments. Monitoring farmland preservation is carried out periodically by satellite survey. In this context, although the central and city governments share the common goal of economic growth, the bottom line of the central government on farmland protection becomes a barrier to city governments who wish to develop land to achieve growth. Under the policy of decentralization in particular, where a city government is expected to behave like a business enterprise that has to be self-financing, rural land is the most valuable resource for gaining revenue and attracting investment. Therefore, the relationship between the central and city governments is complicated when it comes to the trade-off between economic growth and farmland conservation. While city governments demand rural land for development to gain fiscal revenue, the central government aims to preserve it.

The inconsistency in the management of rural land development seems to be more problematic when looking at the relationship between township government and the higher levels of government. Township governments often have a positive attitude towards informal land development, such as in Foshan [35] and Shenzhen [21]. Township governments may not share the goal of growth with their respective city governments. As we saw above, one of the major missions for a township government is to guarantee social stability and improve the quality of life in rural areas. Selling and leasing rural land to factories and enterprises or self-developing housing for sale on the market are two important ways for township governments to create jobs and increase villagers' income. Although recognizing the illegality of informal development in villages, township governments either support or turn a blind eye to these development activities. In some cases, township government even helps villages to conceal informal land development to avoid controls from the city government and the Ministry of Land and Resources [20]. This inconsistency in the goals and needs of city and township governments in relation to informal land development occurs in many provinces, for instance in Hainan [20] and Henan [36].

Moreover, there is a difference between urban and rural land management. Urban land development is strictly regulated by a sophisticated regulation system; that is, "One approval for development location choice and two permissions for land use and building construction" (Yishuliangzheng). The whole development process, from site selection, planning, and design to construction, is strictly controlled by the city government. The Urban Planning Law enacted in 1990 ensures this management system. However, there was no law for rural land development or construction regulation until 2008 when a new Urban and Rural Planning Law came into effect. Before 2008, construction in villages was completely outside the control of state and city governments. Although this new law demands a strict management system for land development in rural areas, this system is still considered to be impractical because township governments are required to be the main management agency for rural land development. 


\section{Informal Land Development in Beijing}

\subsection{Research Method}

The original investigation presented in this paper was conducted during the period from October to December 2015. The investigation is one research content of the national key project "Investigation of the roles and functions of township in China", which is funded by the Ministry of Housing and Urban \& Rural Development of China. In the study, qualitative methods are applied to investigate the role of villages and townships in informal land development in China by looking at Beijing as a case study. Firstly, the overall situation of informal land development in Beijing is analyzed. Secondly, the case of Doudian town is analyzed. Several in-depth interviews with local officials were conducted to reveal the deep institutional factors involved in informal land development.

There are several reasons why Doudian town was chosen as a case study in Beijing. Doudian is a typical suburban township on the city fringe of Beijing (Figures 2 and 3). The national highway G7 and several local expressways cross Doudian. Doudian has a high level of accessibility to the Fangshan district center and the city center. There are 30 rural villages inside its administrative boundaries. Most land in Doudian is collectively owned by villages. Like other suburban townships, Doudian has experienced a rapid urbanization process since the 2000s. Thousands of migrants have moved in Doudian. The huge demand on housing brings an opportunity for informal land development. Detailed information about informal land development in Doudian is introduced in the next section.

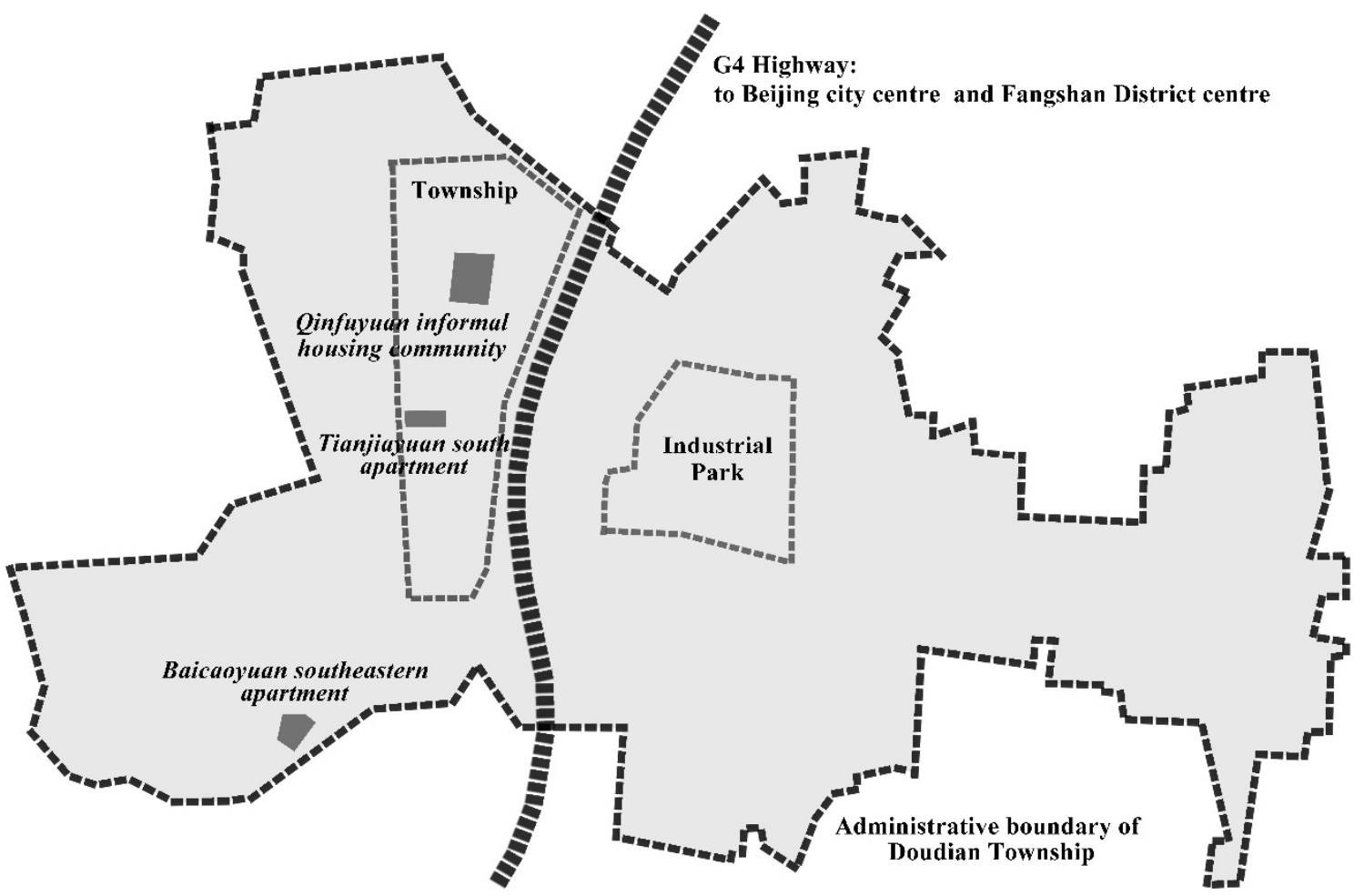

Figure 3. The layout of Doudian town.

The authors conducted face-to-face semi-structured interviews with nine officials. Four of them are in charge of urban and land use planning and management in Doudian township. Three of them are government financial officials in Doudian township. The other two interviewees are from the mayor's office and are familiar with the township land management in Doudian. These interviewees were asked how informal land development occurred in Doudian, who developed the informal gated communities, who bought houses in these informal gated communities, what the local township government's attitudes are towards the informal gated communities, why the local township cannot 
stop the informal land development, and other questions related to land management. Each interview lasted 30 minutes to two hours. Some questions to the interviewees were open. After the interview, two of the local officials accompanied the authors to conduct field surveys.

\subsection{The Overall Situation}

The city of Beijing is China's capital. It has a land area of $16,410 \mathrm{~km}^{2}$ and had 21.5 million residents in 2014. The administrative area of Beijing consists of three areas: the central urban area, the inner suburban area, and the outer suburban area (Figure 2). Each of these areas includes several districts or counties. In the process of rapid urban expansion, the inner suburban area has become a major new area for housing and industrial development. As a result, the municipal government of Beijing has changed the status of rural counties in the inner suburban area into urban districts, as they already have a large urban population and cater for industry. However, it should be recognized that these newly identified urban districts still have many rural towns and villages inside their administrative boundaries. Most of the land in these new urban districts is still rural land that is owned by villages.

Not surprisingly, these districts in the inner suburban area have become the major areas in which informal land development and informal housing construction have occurred, with almost $80 \%$ of informal housing in Beijing located in villages in these areas. According to the "Real estate market report" [1], the total amount of informal housing was very high, accounting for $20 \%$ of all houses sold on the real estate market in Beijing in 2012. From 2006 to 2010, a floor area of 4 million $\mathrm{m}^{2}$ of informal housing was developed [1].

Soaring housing prices and the state government's control of real estate speculation have only boosted the informal housing market. A 'restrictive policy on housing purchase' was applied in 2009 to stop real estate speculation in Beijing. According to this policy, residents without Beijing hukou (urban residential registration) are not permitted to purchase housing in Beijing unless they have paid social insurance in Beijing for five years. The hukou system was established in the 1950s as a means of controlling population movement between rural areas and cities and between cities [37]. The hukou system divided the population of the whole nation into two groups: people with urban hukou and people with rural hukou. In the pre-reform era, rural residents with rural hukou were not allowed to migrate freely to the city and take advantage of the generally higher living standards there. Since the 1980s, reforms have been implemented, relaxing the hukou system and allowing migrants to work and live in the city, and this has been the main driving factor in the process of urbanization. The number of migrants from rural areas to cities increased from 70 million in 1993 to 210 million in 2008 , thus exceeding $15 \%$ of the national population and accounting for $42 \%$ of all rural laborers (CSB, various years). Migrants to China's cities without local urban hukou are also called a "floating population". Since the 1990s, the implementation of reforms to the hukou system has increasingly become the role of the national government and municipal governments. The function of hukou as a tool of household registration has been declining. However, the hukou-related social welfare system and associated institutional arrangements still exist without obvious changes. Migrants without local urban hukou are still disadvantaged in accessing low-price housing subsidized by local governments, medical facilities, and even schools. Migrants had made up a huge part of the population in Beijing, with 7 million in 2010. Nearly $40 \%$ of these people have no Beijing hukou. Most of them are low-income earners and are engaged in informal employment or temporary work with no social insurance and thus they have no capacity to buy formal housing. As a result, they have to buy informal housing, if any. Moreover, housing prices have been soaring since 2007. By 2015, the average housing price in Beijing reached CNY 30,000/ $\mathrm{m}^{2}$, meaning a two-bedroom apartment could cost as much as CNY 3 million. However, a worker's average annual wage is only CNY 77,000, with the ratio of housing price to annual household income now 20:1 on average. Housing affordability thus seriously challenges the quality of life for rural-urban migrants. With the price of informal housing usually one third of that of formal housing, there is a substantial informal housing market in Beijing. 
In addition, the Ministry of Land and Resources introduced a policy limiting land supply for villas in 2006 in order to promote intensive land use. Villa real estate was thus inhibited in the formal housing market. However, there remained a huge demand for villas due to the increasing growth of the middle-class in China. In this context, informal villas developed in previously rural areas have gained popularity on the market, making up a sizable part of the total informal housing stock in Beijing (Figure 2).

The municipal city government is strongly opposed to these informal land developments, with a variety of approaches having been applied to deal with the gated informal housing communities, depending on the context (Table 1). Firstly, with respect to the gated informal housing community developments which occupy farmland, the city government claimed they must be completely demolished. An administrative form of punishment-for example, an oral warning-was delivered to township governments and villages where the informal housing had been developed. However, it is impractical to demolish this housing as it could directly cause a huge economic loss to thousands of buyers. If the informal housing in the gated informal housing communities was demolished, it would be impossible for the buyers to obtain compensation from the developers and villages because of the illegal purchase contracts. In addition, some commercial services developed for the gated informal housing community could be close as well, such as shops, private schools, medical centers, markets, etc. Thus, the demolition of informal housing actually encounters many difficulties and is often criticized by the public. The city government has already realized that it is very important to maintain social stability, and the demolition of informal housing may not be the best way of solving the problem. This is the reason why only seven out of 83 of the gated informal housing communities have been demolished thus far.

Table 1. The responses to the gated informal housing community from the city government of Beijing.

\begin{tabular}{|c|c|c|c|}
\hline \multicolumn{2}{|c|}{ Situations } & \multirow{2}{*}{$\begin{array}{l}\text { The Responses to Informal } \\
\text { Housing } \\
\begin{array}{l}\text { Strictly oppose, Punish a township } \\
\text { government and village, Demolish }\end{array}\end{array}$} & \multirow{2}{*}{$\begin{array}{c}\text { Case } \\
\text { Liulinyuan flats, } \\
\text { Daxing District }\end{array}$} \\
\hline $\begin{array}{c}\text { Informal } \\
\text { development }\end{array}$ & $\begin{array}{l}\text { Sold out with } \\
\text { occupancy }\end{array}$ & & \\
\hline occupying farmland & Under construction & $\begin{array}{l}\text { Strictly oppose, Punish a township } \\
\text { government and village, Demolish }\end{array}$ & $\begin{array}{c}\text { Nongjia villas, } \\
\text { Tongzhou District }\end{array}$ \\
\hline \multirow{2}{*}{$\begin{array}{c}\text { Informal } \\
\text { development } \\
\text { without occupying } \\
\text { farmland }\end{array}$} & $\begin{array}{l}\text { Sold out with } \\
\text { occupancy }\end{array}$ & $\begin{array}{c}\text { Oppose, Require retrofit to match } \\
\text { state construction standards, Land } \\
\text { use remains illegal }\end{array}$ & $\begin{array}{l}\text { Fuyuan community, } \\
\text { Changping District }\end{array}$ \\
\hline & Under construction & $\begin{array}{l}\text { Oppose, Confiscate and retrofit, } \\
\text { Reuse as affordable housing or } \\
\text { remain unused }\end{array}$ & $\begin{array}{l}\text { Cunweihui community, } \\
\text { Yanqing County }\end{array}$ \\
\hline
\end{tabular}

Secondly, in relation to informal developments that only occupy collective construction land in a village or the sites of the villagers' own homes, without occupying farmland, the city government has actually done little to prohibit them. In relation to the informal housing that was sold, the city government just required owners to retrofit these illegal buildings in accordance with the state construction standards. The land use of these housing sites remains illegal. In relation to the gated informal housing community that was under construction, the city government has confiscated it. In some cases, the confiscated housing of good quality has been legalized and used for the state's social housing. However, in most cases, the confiscated housing has remained empty and unused for many years. 


\subsection{The Case of Doudian Township}

\subsubsection{Development Context in Doudian}

This section examines the case of Doudian town, a suburban township located in Fangshan District (Figures 2 and 3). Several informal housing projects were developed in the town, which has many advantages over other towns, such as proximity to the district center, a large population and industrial parks. The national motorway, the G4, connects the town to the city center of Beijing and other cities. Due to these advantages, Doudian town is growing fast. It had a population of 90,000 with a $64.58 \mathrm{~km}^{2}$ land area in 2010, and it has attracted the attention of many real estate developers.

Like other suburban townships in Beijing, Doudian has witnessed the rapid growth of informal housing since the 2000s. Three informal housing sites have been confirmed by the municipal government in Doudian. They are the Qinfuyuan community in Yuzhuang village, the South Apartments in Tianjiayuan village, and the Southeast Apartments in Baicaowa village (Figure 3). Most of this informal housing was developed during the period 2002 to 2006. There are two types of informal land development: large-scale informal residential communities and scattered informal housing. The former are the gated housing communities, in which the quality of the housing is high (Figure 4). For example, Qinfuyuan is one of the largest informal gated housing communities in Doudian (Figure 3). There are 648 apartments in the community, in which nearly 3000 people live. The community is serviced by bus, shops, supermarkets, parks, etc.
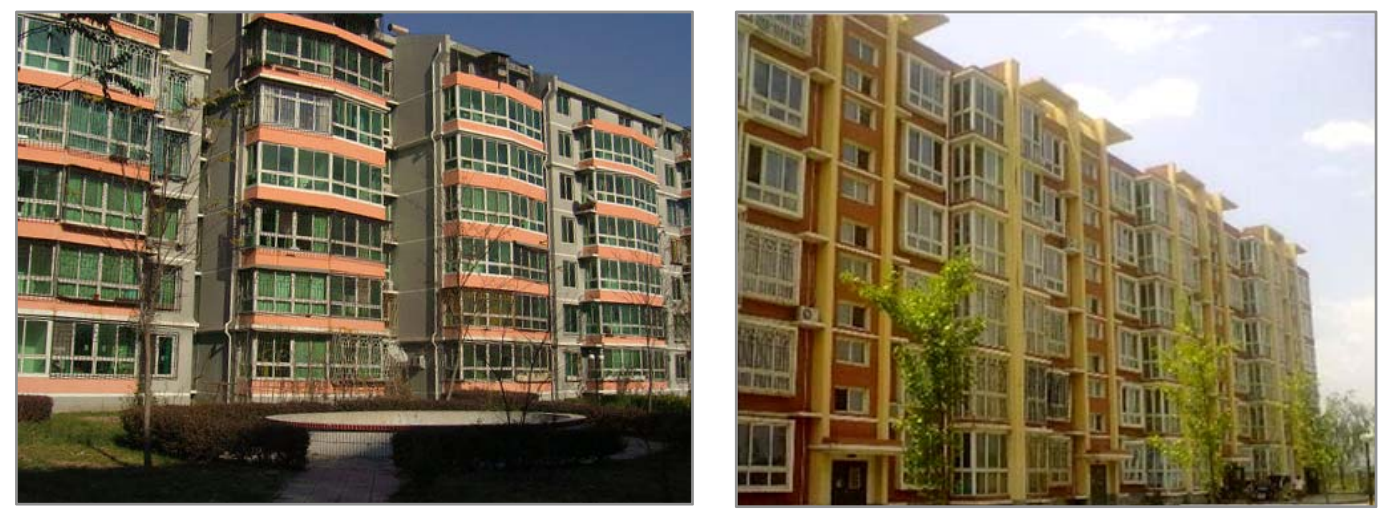

Figure 4. Informal housing in Doudian.

\subsubsection{Interviews about Informal Land Development}

This study conducted in-depth interviews with local officers from the Doudian township government and the higher government of Fangshan District, investigating the roles and attitudes of the township government and the city government to these informal developments.

\section{Theme 1: The Role and Attitudes of the Township Government}

The attitude of the Doudian township government to informal housing was rather ambivalent. The officials in the government considered that it is impossible to completely eradicate informal housing and informal land development unless villagers' livelihoods are protected by alternative means. To some extent, the officials consider that the prohibition of informal land development may negatively affect villagers' livelihoods. Most villagers in Doudian are no longer active in agriculture, even though they are still peasants. Without an education or other skills, villagers are unlikely to find formal jobs in the city. At the same time, it is hard for the Doudian government to provide many employment opportunities or welfare to villagers, due to its low fiscal revenue. As a result, informal land development has become one of the most important sources of income for the villagers to ensure their livelihoods. The township government turns a blind eye, or even acquiesces to the 
informal land developments and informal housing in villages. The township government agrees that informal land developments have brought wealth to the villages and guaranteed villagers' livelihoods. An official revealed that one village had a CNY 100 million deposit in its account. They know the money was obtained through informal land development. However, the official stated that the township government holds a neutral position on this because the money helps the village to improve social welfare.

Interview 1: This village has CNY 100 million in its private account. The village may resettle villagers in multi-story buildings and lease or sell land to developers in both formal and informal ways. This is common because the village has to ensure that its villagers have a good quality of life. Although the villagers were relocated and live in multi-story buildings, they are still seen as peasants and cannot enjoy welfare benefits and insurance from the city government. This is because they are not urban residents but farmers with non-urban hukou. The old people, especially, don't have any source of income except bonuses from the village's private account. We [the township government] have not the ability to provide welfare to them either [38].

Interview 2: We don't have money to provide enough jobs for the villagers. Street cleaning is the most common job that we can offer to the villagers. However, more and more villagers want this kind of job. But we don't have enough money to increase the number of such jobs, even though we need more people to clean the streets. Thus, a job position may be shared by several villagers. They are employed part-time and work at different periods of time during the day [38].

Informal development of rural land has thus become a vital way for villagers to obtain an income and maintain their livelihood. Most villages in Doudian, especially those in close proximity to the township, are no longer involved in agricultural activities. Many villagers have leased their farmland to professional farming companies. However, these villagers are excluded from the urban social security and welfare system because they are considered to be peasants and are not granted urban hukou. These rural villages thus struggle to provide some form of welfare for themselves.

A collective economy lies at the root of all villages and there are many ways for a village to enhance this collective economy. One new method has arisen as a result of the introduction of a land quota policy in Beijing, designed to control the loss of land. Due to this policy, land for further development in the existing built-up area is now scarce, and the rural land in peripheral villages is becoming attractive to private developers, who approach the villages and encourage them to sell their rural land. While these private developers pay a land use right fee to the villages, it should be recognized that this transaction and thus the income from this sale of rural land is illegal and completely out of sight of the state and the municipal governments. As a result, there is also a degree of corruption among the village cadres, who appropriate land revenue for themselves. This has become a new social issue in rural areas.

The villages in Doudian town play an active and aggressive role in informal rural land development, collaborating well with private developers. However, it is interesting to note that the Doudian township government is rarely involved in any collaboration with developers. This contrasts with the conventional behavior of township governments, who generally do collaborate closely with private developers in informal land development. As mentioned above, the wealthy village that has saved CNY 100 million has a well-considered scheme to develop its land. Three years ago, the village cadres even intentionally moved the villagers from the village to new multi-story buildings, then cleared and prepared the land before a developer was chosen to develop the land. A small developer first negotiated with the village but failed. One year later, one of the best and powerful developers in China, the Vanke Real Estate Corporation, arrived on the scene and claimed they had an approach that would legalize the informal land for formal development. Subsequently, the village agreed to sell the land to the developer.

The Doudian township government had no say during the entire process. After the village and the developer had reached a deal, the township government even assisted the developer to make 
the illegal transaction legal. The township government actually gained a benefit in the form of a management fee that was submitted by the village. Nevertheless, the amount that the township government received was small, with most of the land-transfer fees given to the villagers by the developer in advance. Despite this, the township government did not object to the informal deal but, on the contrary, regarded this as a good way for villages to increase their income and improve their livelihoods. In addition, the township government welcomed other influential developers wishing to undertake urban development in the villages as they believed this could enhance the town's living environment, change the poor image of the town, and thus attract more investment.

Most of the buyers and residents now living in the informal housing are not locals. However, the township government has a very positive attitude to the immigrants and the buyers because they are relatively wealthy and contribute to local economic growth. Many villagers now run small businesses in the town, such as supermarkets, restaurants, and grocery stores, and immigrants are their main customers.

Interview 3: Half of the residents are immigrants. Most of them work in the city center, Changyang town center, and Liangxiang town (the government center of Fangshan district). They are important. The villagers have set up some small businesses to cater for these wealthy immigrants. Most groceries, restaurants, and other shops are operated by villagers and these immigrants are their main clients [38].

The township government even has sympathy for the informal housing owners. The infrastructure, such as electricity, gas, water, and drainage, in informal housing communities is usually provided by the developers and villages. Such infrastructure is separate from the municipal services because of the illegality of the informal housing. Most of these services are poor in quality and cause environmental pollution. The township government, indeed, has no duty to provide infrastructure and services to the residents living in the informal housing communities. However, with a strong concern for both the environment and social stability, the township government is very willing to provide infrastructure to the residents living in the informal housing communities rather than merely demolish them, as the city government wishes.

Interview 4: It is impossible to stop their (residents in informal housing) heating and water supply. They have to live there. The winter is so cold. But the pollution caused by burning coal is very serious. The drainage is so poor that sewage flows into farmland and pollutes underground water. If we had enough money, we would really like to provide good infrastructure for them [38].

Theme 2: The Weaknesses of the Township Government

As for the implementation of the regulations set by the city government, the township officials said that there is no doubt that they should implement the regulations, but that they have no enforcement powers to prevent informal housing development. The only thing that a township government can do is to warn the villagers and request them to stop informal land development before the officials from the city government come to enforce demolitions and impose fines. In other words, the land use and development management rights remain in the hands of the city government of Beijing and the land resource bureau and planning bureau of the city government remain the authorities in charge of land use and development management. However, these municipal administration departments have almost no direct relationship or communication with the Doudian township government. They communicate with the Fangshan district government, which has jurisdiction over Doudian township. This means the direct superior of the Doudian township government in relation to informal housing development is the Fangshan district government, rather than the powerful departments of the city government. This inefficient administrative structure has reduced the ability of Doudian township government to manage informal land development in its rural area. 
Interview 5: We don't have enforcement powers. We can warn them (villagers) but it is useless. And it is really hard for us to monitor informal land development in villages. It (leasing or selling land) is their internal affair, we can't step in. And the villages are very complicated [38].

The officials also highlighted a financial dilemma that the township government had been struggling with. The annual fiscal revenue of Doudian was approximately CNY 7.6 billion. This is relatively small compared to its expenditure needs for many local affairs. Since 2010, the township government has faced a challenge: maintaining fiscal revenue from land development as the central government introduced a national policy of "shrinking new land development and promoting land efficiency." The township is thus short of funds to support rural development. The officials stated that they must allow some villages to develop the local economy by themselves. For example, to develop a tourist village, one official emphasized, a primary task is to find funds to improve local infrastructure. Since both the township and the villages are short of funds, informal land development could be a realistic and practical way of securing start-up funds. In this situation, the township government is unlikely to oppose informal land development.

Interview 6: We don't have money and a land quota. It is impossible for us to develop the town economy without funds and land. If a village can transform into a tourism village, the villagers will have solid incomes. We support their ideas and their development activities. But without funds and land, how can we support them? The only thing we can do is to let them do what they want to do [38].

The growing power of private developers is another major factor influencing informal land development in rural areas. The villages usually sell their land to developers in the form of a lease for a given period, such as 70 years. Subsequently, the developers build housing on the land and sell the houses to private buyers. This development is typically illegal since the land transfer was not legal. However, some powerful developers such as Vanke can ensure the land use is legal. They are wealthy and have the power to influence the local property market. They also have an influence on the local policymaking process at both the Doudian township level and Fangshan district level. In most cases, the developers not only pay tax to the township government but are also important contributors to local public facilities, such as schools, roads, and parks. The villages clearly realize the important role of these large developers and usually choose to collaborate with them, giving them permission for informal land development. These powerful developers, indeed, have sufficient political resources and alternative ways to make their development collaboration activities with the villages legal. When a coalition between a large developer and a village is formed, the township government has a very limited role when it comes to intervening in their development activities.

\section{Theme 3: Irrational Land Use Policies}

The officials considered that the existing land use policies designed to control land development in Doudian are unreasonable and unfeasible. Doudian town is located in the urbanized area and is relatively close to the center of Beijing. There is no need for the town to preserve a large amount of farmland. However, the existing land policy of the Ministry of Land and Resources still requires the town to preserve farmland. According to the land plan, some farmland designated for preservation is even located in the town's central area. These plans have impeded the improvement of the urban living environment and land use efficiency in Doudian. In addition, there are conflicts between the land use plan of the land bureau and the urban plan of the urban planning bureau. The land use plan is focused on the preservation of agricultural land, while the urban plan is focused on the provision of land for urban development. In some cases, these two types of plans do not match with each other. Land use plans often ignore the town's rapid urbanization. Many industrial and housing development plans cannot be put into practice because of a shortage of land.

However, it is difficult for the township government to change a land plan according to the existing land use policy. Moreover, China's land use and development is strictly managed by a 
land construction quota system. The central government gives a certain land development quota to provincial governments, which distribute this land quota to cities. Afterwards, the city government distributes the land quota to districts and counties, which then make plans for land use and urban development according to the land quota. Thus, a township government has no right to make a decision on land quotas. In practice, it rarely receives a sufficient quota to allow development, as most of the land quota is taken by the city government for development in the urban areas.

Interview 7: I don't know why the higher government is still asking us to preserve so much farmland. The villagers are no longer coming back to do farming. Some preserved farmland is even in the town center. New roads have to change direction to avoid it (preserved farmland). It is a waste and a bad thing for the town's landscape. The developers, investors, and buyers won't like such weird surroundings [38].

Industrial land use policy is another barrier to development in Doudian. While there are industrial parks and manufacturers in Doudian town, the officials from the township government do not think the township actually benefits much from these huge industrial and development projects, which are led by the city government. Most of the taxes paid by the industrial enterprises are collected by the city government. Thus, the township government receives a small amount of the tax but contributes with a large amount of land. For example, Changan Automobile Group, one of China's largest car manufacturers, built a large-scale R\&D industrial park in the town. This project was actually led and supported by the city government. Doudian township government, however, has a negative attitude to the project. The reasons are complicated. Firstly, this R\&D park has an independent management committee that is directly led by the city government. The township government has no rights to intervene in the development of the industrial park. Secondly, this industrial park uses the land quota that should have been allocated to Doudian. However, the township government did not receive any land-transfer fees because the city government waived them in order to attract the manufacturer. Thirdly, this industrial park is only used for R\&D, with the main production lines, sales agencies, and headquarters located in Chongqing City. This means that the industrial park only brings in a small amount of revenue to the township government.

Interview 8: It (the industrial park) occupies our construction land quota. The city government provides much support and the land use is legal, but we receive little tax. The manufacturer registered its office in Chongqing and there is no production here. It has its own committee. We can't manage it. Most of the benefits go to the higher (city) government; we receive little [38].

Nevertheless, the township government acknowledged the potential benefits of the industrial park, which offers some low-end and temporary jobs to local villagers. The industrial park even provides training for villagers in various work skills. The township government agrees this could assist in reducing unemployment.

Interview 9: It [the industrial park] welcomes the villagers to work. These jobs are very easy and flexible. The location is close to the villages. Most villagers have to look after their elderly parents in the villages. Therefore, these jobs are very popular among villagers. The company even trains some young villagers and sends them to other factories in other cities. It's very helpful to improve their livelihoods [38].

To sum up, the above interviews and discussions unfold the role of township governments and villages in the development of gated informal housing communities. Doudian township government has an ambivalent altitude to informal land development, although the township government is facing strong requirements from the state government to control informal land development. In most cases, township governments may give tacit consent to villages' illegal land development activities. Apparently, there are growing conflicts between the state control and local land management. One of the major reasons for this is that informal land development could bring economic income to the 
villages and the township. Another reason is that the township actually has limited power to control informal land development in the context of marketization. The market-oriented reforms make land management more fragmentized. Multi-scale forms of governance with multi-stakeholder arrangements (MSAs) emerged in urban development in China [39]. In this multi-stakeholder arrangement system, the conflicting interests are allowed and the negotiation between the government, village and other sectors replaces the mere command control from government. As a result, the increasing market activities in local economic and land development and multi-stakeholder arrangement weaken the management power of a township government. The situation seems to become worse when the disadvantages of the existing land use policies are taken into account. In particular, the irrational land use policies from the state bring challenges to the implementation of the land development management for township government.

\section{Discussion and Policy Implications}

This paper analyzed the processes behind the new trend in informal land development and related factors in China. The study took a different perspective from the conventional understanding of informal land development as the result of the existing dual urban-rural land ownership system $[2,4,19]$. Instead, looking at the case of Beijing and the township of Doudian in particular, the paper addressed the role of villages and townships in informal land development and the conflicts with state regulations. In particular, several different types of institutional barriers to land development management are addressed. They are: land use management and planning, governance structure and political decentralization, resource allocation and distribution of land benefits, and the attitudes of township government and officials to informal land development. Based on the analysis above, several important points in relation to institutional capacity building are discussed below.

Firstly, the conflict between state regulations and the need for local development could be the most important reason for informal land development on the city fringes. The previous literature has found that, according to the existing land development management system, the distribution of land revenues arising from the process of rural land development between villages and the state is highly imbalanced $[1,4]$. Most of the revenues are collected by the state and city governments, with the villages and their inhabitants only receiving a small proportion of the revenues that are produced from their land. Thus, informal land development could be considered a form of resistance by villages to the loss of economic benefits accruing from the added value of the land [16]. Grassroots governments, for example township governments, could have more direct and important effects on informal land development.

The analysis above demonstrates that township governments, indeed, have a rather ambivalent attitude towards informal land development. Rapid urbanization has meant that most villagers no longer engage in agricultural activities. However, the state offers little welfare and social security assistance to these unskilled villagers. Township governments will not prevent informal land development and even believe these informal developments could play a positive role in improving the quality of life in the rural areas. In reality, township governments have very limited power to control informal land development when a coalition between villages and powerful developers is formed. Growing marketization is giving more power to developers. In this context, the role of township governments in managing rural land development is only declining more.

Township governments do not always stand in line with the city government. As mentioned above, unlike the city government, which focuses on economic growth, township governments pay more attention to social stability and the quality of life in rural areas. To a large extent, township governments tend to share the same goals as rural villages, rather than the state and the city governments. Informal rural land development is seen as one way to increase villagers' income and obtain revenues to provide welfare and public services in rural villages. Especially in the context of decentralization, township governments are faced with a shortage in finances but an increase in 
their responsibilities in the provision of public services. In this context, informal land development may relieve the township government's burden of providing services in rural areas.

In this light, it is apparent that "local-state corporatism" and urban entrepreneurialism do exist in China, but may merely occur at the level of the city government. Both villagers and township governments may actually become victims of such "local-state corporatism" if they only obtain small economic benefits from land development projects led by the city government. In some instances, the city government actually expropriates scarce and valuable construction land from township governments to support city-level development schemes. This finding is inconsistent with previous studies that suggested that township governments play an active role in such "growth coalitions" $[17,18]$.

Moreover, township governments re facing an institutional dilemma in managing land development in rural areas. Township governments are expected to be responsible for both farmland preservation and construction management in villages. However, township governments have a very limited capacity to implement municipal regulations. The process of decentralization in China has had various effects: more state powers have been transferred to provincial and city governments, while village autonomy has also increased. However, enforcement powers remain more centralized, lying not with district and township governments but at the city government level. As a result, township government suffers from a variety of weaknesses in managing informal land development in villages.

In addition, the fragmented planning system in rural areas is another factor influencing informal land development. In China, urban planning provides the legal basis of urban land use and development management. Any development and construction permissions must be issued under the statutory planning authority. However, urban planning regulations are often ignored in rural areas. One of the reasons for this is that the land is collectively owned in these rural areas. There are also conflicts between urban planning and land use planning. While the latter is focused on farmland preservation, the former is focused on fostering urban development. A township that is keen to develop its local economy is often faced with a complex process of negotiation between land use planning and urban planning authorities.

According to these findings, policy interventions that tighten regulations without institutional reform may be insufficient and impractical to curb informal land development. It is irrational to arbitrarily prohibit informal land development, because it is one important way of improving villagers' livelihoods. Policy interventions for the purpose of curbing informal land development should instead aim to: (1) meet villagers' needs for a sustainable livelihood; (2) balance fiscal revenues and fiscal responsibilities between the central and local governments; and (3) give greater administrative power and autonomy to township governments. These goals could be achieved through the following institutional changes.

Firstly, villagers' livelihoods should be further guaranteed in a sustainable manner. It is irrational to expropriate rural land by giving a one-off compensation to villagers. Many studies have indicated that peasants who have lost their land have no skills that would allow them to find a job, and they do not have an appropriate plan to use the compensation to further their livelihoods [40,41]. Once they have spent all of their compensation, they have nothing left to live on. Land transfer should thus be linked with social welfare in rural areas. In addition, city governments often fail to grant farmers urban hukou after their lands are expropriated. As a result, farmers who lose their land cannot enjoy basic urban welfare and social insurance, even though their lands have become part of the city. Therefore, it is necessary to adopt policies that ensure full and reasonable economic benefits to villagers when their land is expropriated.

Secondly, township government, a direct administrative unit in the rural area, should be given sufficient rights and powers to manage land development. In practice, the central government has paid a great deal of attention to the dilemmas faced by township governments. Administrative reform aiming to give more powers and liberty to township governments has already begun. At the same time, however, it is necessary to allocate more taxes to township governments in order to enhance their 
capacity to improve the quality of life in rural areas. Service-oriented grassroots government should be established.

Thirdly, it is not feasible to apply universal land policy to all towns across the whole country. Some towns, especially those located close to metropolitan regions, are faced with great pressure to develop and urbanize. These towns may already be in a rapid process of transformation from a rural to an urban area. The villagers in these towns are no longer engaged in farming. This means that strict farmland preservation in these towns is possibly impracticable. Therefore, different land policies should be designed and applied according to local conditions. In other words, for towns in urbanized areas, land use policy should be more flexible.

Finally, urban growth need not occur at the expense of village and township development opportunities. Land revenues from rural land development should be fairly distributed between the state government, villages, and township governments, with the latter given access to reasonable land revenue in order to build infrastructure, supply public services, and provide better welfare in the rural areas.

\section{Conclusions}

This paper discussed the phenomenon of informal land development, which has taken place since the 2000s, and considered the implementation of state land development regulations at the grassroots level, such as by village and township governments. In particular, it investigates the role of township government and villages in the development of gated informal housing community. The conflict between state regulations and local development needs is one of the most important factors affecting informal land development on the city fringe. Decentralization and marketization have significantly changed the roles of different levels of government. While "local-state corporatism" and urban entrepreneurialism do exist in China, this mainly occurs at the level of city government, with both villagers and township governments likely to be casualties of this "local-state corporatism" in the current land development management system.

Decentralization and marketization have significantly changed the roles of different levels of government. Township governments do not always share the goal of growth with their respective city governments. Unlike the latter, which are keen to stimulate economic growth, township governments are more concerned about the quality of life and social stability in rural areas. Consequently, township governments have an ambivalent attitude towards informal land development, which actually brings economic benefits to local villagers and themselves. The situation seems to be worse as townships have poor fiscal capacity and a growing administration responsibility for improvement of local development in the context of decentralization. Villages are keen to capture economic benefits from informal land development with help from private developers. As a result, a locally informal coalition between townships, villages, and private developers emerged at the grass-roots level.

These findings reveal the complexity underlying informal land development in China. In relation to future policy, informal land development will probably continue unless the issue of villagers' livelihoods is addressed, and the lack of balance between different levels of government in relation to fiscal revenues and responsibilities has been resolved. Policies designed to curb informal land development should integrate social welfare and long-term sustainable goals. In particular, inclusive social policies should be addressed in future rural land development policymaking.

Acknowledgments: This research is funded by the NSFC project No. 41571147.

Author Contributions: Pengjun Zhao wrote the main framework, the introduction, the discussion and the conclusion section of the paper. Mengzhu Zhang wrote the literature review and the analysis section of the paper, and contributed to the date collection.

Conflicts of Interest: The authors declare no conflict of interest. 


\section{References}

1. Ren, Z.Q. Limited Property Right Problem Research in China: The Present Situation and the Way Out. Available online: http://blog.sina.com.cn/s/blog_4679d3510102dtt0.html (accessed on 1 March 2012). (In Chinese)

2. Lin, G.C.S.; Ho, S.P.S. The state, land system, and land development processes in contemporary China. Ann. Assoc. Am. Geogr. 2005, 95, 411-436. [CrossRef]

3. Zhou, Q. The Urban and Rural Areas of China; China Citic Press: Beijing, China, 2013. (In Chinese)

4. Wu, F.; Zhang, F.; Webster, C. Informality and the Development and Demolition of Urban Villages in the Chinese Peri-urban Area. Urban Stud. 2013, 50, 1919-1934. [CrossRef]

5. Zhang, L.; Zhao, S.X.B.; Tian, J.P. Self-help in Housing and Chengzhongcun in China's Urbanization. Int. J. Urban. Reg. Res. 2003, 27, 912-938. [CrossRef]

6. Zhao, P. Managing urban growth in a transforming China: Evidence from Beijing. Land Use Pol. 2011, 28, 96-109. [CrossRef]

7. Nandao Evening News. Sanya City Yesterday Demolished 12000 Square Meters of Limited Property Right Houses. Available online: http://ndwb.hinews.cn/html/2018/14/content_7_1.htm (accessed on 14 August 2014). (In Chinese)

8. Xinkuaibao News. Give all to Purchase Limited Property Right House, 40 Workers Lose Everything. Available online: http:/ / epaper.xkb.com.cn/view/752641 (accessed on 31 December 2011). (In Chinese)

9. Hangzhou Daily. Beijing Started to Demolish Limited Property Right Houses. Available online: http://hzdaily.hangzhou.com.cn/dskb/html/2016/03/content_880826.htm (accessed on 3 June 2010). (In Chinese)

10. Beijing Daily. Hebei Publicly for the First Time Demolished Limited Property Right Houses. Available online: http:/ / finance.chinanews.com/house/2013/16/5621008.shtml (accessed on 6 December 2013). (In Chinese)

11. Jiangsu News. Compensation for Demolition of Limited Property Right Houses in Tiexinqiao raised questions. Available online: http://jsnews.jschina.com.cn/system/2014/12/24/023065072.shtml (accessed on 23 December 2014). (In Chinese)

12. Chow, G.C. China's Economic Transformation, 2nd ed.; Blackwell Publishing Ltd.: London, UK, 2007.

13. Wei, Y.D. Decentralization, marketization and globalization: The triple process underlying regional development in China. Asian Geogr. 2001, 20, 7-23. [CrossRef]

14. Chien, S.; Wu, F. The Transformation of China's Urban Entrepreneurialism: The Case Study of the City of Kunshan. Cross Current. East Asian Hist. Cult. Rev. 2011, 1, 1-28.

15. Hua, S. Transformation of Urbanization and Land Trap; Oriental Press: Beijing, China, 2013. (In Chinese)

16. Zhu, J. Urban physical development in transition to market. The case of China as a transitional economy. Urban Aff. Rev. 2000, 36, 178-196. [CrossRef]

17. Zhang, T. Urban Development and a Socialist Pro-growth coalition in Shanghai. Urban Aff. Rev. 2002, 37, 475-499. [CrossRef]

18. Zhu, J. Local growth coalition: the context and implications of China's gradualist urban land reforms. Int. J. Urban Reg. Resear. 1999, 25, 534-548. [CrossRef]

19. Guo, X. Land expropriation and rural conflicts in China. China Q. 2001, 166, 422-439. [CrossRef]

20. Wang, Y.; Scott, S. Illegal Farmland Conversion in China's Urban Periphery: Local Regime and National Transitions. Urban Geogr. 2008, 29, 327-347. [CrossRef]

21. Li, L.; Li, X. Redevelopment of urban villages in Shenzhen, China-An analysis of power relations and urban coalitions. Habitat Int. 2011, 35, 426-434.

22. Zhou, Z. The Integration of Urban and Rural Development in the Process of Development of Township Government Governance. Ph.D.'s Thesis, Soochow University, Suzhou, China, 2014. (In Chinese)

23. Xu, Y.; Zhu, T. Service-oriented township government: reasons and construction. China Publ. Admin. 2009, 294, 86-89. (In Chinese).

24. North, D.C. Institutions, institutional change, and economic performance; Cambridge University Press: Cambridge, UK, 1990.

25. Zhao, P. The evolution of the urban planning system in contemporary China: An institutional approach. Int. Dev. Plan. Rev. 2015, 37, 269-287. [CrossRef]

26. Gilbert, A.; Ward, P. Housing, the State and the Poor; Cambridge University Press: New York, NY, USA, 1985. 
27. Nijman, J. A study of space in Mumbai's slums. Tijdschrift voor Economische en Sociale Geografie 2010, 101, 4-17. [CrossRef]

28. Zhu, J. From land use right to land development right: Institutional change in China's urban development. Urban Stud. 2004, 41, 1249-1267. [CrossRef]

29. Liu, R.; Wong, T.; Liu, S. The informal housing market in Beijing's rural areas: Its formation and operating mechanism amidst the process of urbanization. Geogr. Resear. 2010, 29, 1355-1368. (In Chinese)

30. China's National Bureau of Statistics (CNBS). China's Fiscal Statistics Yearbook, 2012; China's National Bureau of Statistics: Beijing, China, 2013. (In Chinese)

31. Zhou, F.; Zhao, Y. Analyses of the Local Government Finance: A Case Study in Central and Western China. China Rural Surv. 2003, 4, 25-37. (In Chinese)

32. Tan, Q. Fiscal Decentralization and Functions of the Township Government. China Rural Surv. 2002, 2, 2-20. (In Chinese)

33. Tan, X.; Yuan, Q.; Lu, B. Analysis of the Participation Mechanism of Villagers in Urban Village Reconstruction: A Case Study of Liede Village in Guangzhou City. Trop. Geogr. 2012, 32, 618-625. (In Chinese)

34. Boyle, M.; Hughes, G. The politics of urban entrepreneurialism in Glasgow. Geoforum 1994, 25, 453-470. [CrossRef]

35. Yang, L.; Yuan, Q. A Model of Rural Urbanization Based on Development of Collectively owned Land at the Village Level: The Case of Nanhai, Foshan. Urban Plann. Forum. 2012, 204, 34-41. (In Chinese)

36. Zynews. Zhandian Township Government Involves in Informal Housing Development. Available online: http://news.zzynews.com/2014-09/10/content_9701162.htm (accessed on 10 September 2009). (In Chinese)

37. Zhao, P.; Howden-Chapman, P. Social inequalities in mobility: the impact of the hukou system on migrants' job accessibility and commuting costs in Beijing. Int. Dev. Plann. Rev. 2011, 32, 363-384. [CrossRef]

38. Zhao, P.; (Peking University, Beijing, China); Zhang, M.Z.; (Peking University, Beijing, China). Personal Communication, 2015.

39. Zhao, P.; Lu, B.; Woltjer, J. Conflicts in urban fringe in the transformation era: An examination of performance of the metropolitan growth management in Beijing. Habitat Int. 2009, 33, 347-356. [CrossRef]

40. Chen, H.; Chen, X.; Xie, Y. Occupational Differentiation and Influencing Factors of Land-lost Farmers during Urbanization. China Popul. Resour. Environ. 2013, 23, 72-79. (In Chinese)

41. Zhao, H.; Tong, X. Self-identity of the Passive-urbanized Group in the Process of Obtaining Urban Adaptability and Modernity: An empirical study on 561 land-displaced peasants in Nanjing. Sociol. Stud. 2006, 23, 86-106. (In Chinese) 